\title{
Two-step RT-qPCR analysis of expression of 7 drought-related genes in tomato (Lycopersicon esculentum Mill.)
}

\author{
Ivana Petrović
}

\begin{abstract}
The identification and characterization of genes induced under drought stress is a common approach to elucidate the molecular mechanisms of drought stress tolerance in plants.Examination of gene expression using quantitative PCR (qPCR) in combination with Reverse Transcription (RT) in plant responses to drought stress can provide valuable information for stress-tolerance improvement. The purpose of this manuscript is to describe procedure for two step RT-qPCR analysis of gene expression in tomato leaves, under controled conditions and under drought stress. Described protocol can be adjusted and used for gene expression analysis of different plant species.
\end{abstract}

\section{Introduction}

Climate change is one of the most serious problems facing the agriculture today. In a many countries, drought in conjunction with high temperature becomes a significant risk for sustainable agricultural production. In general, drought stress limits productivity of major crops by inducing different morphological,

\section{How to cite this book chapter:}

Petrović, I. 2019. Two-step RT-qPCR analysis of expression of 7 drought-related genes in tomato (Lycopersicon esculentum Mill.). In: Vucelić Radović, B., Lazić, D. and Nikšić, M. (eds.) Application of Molecular Methods and Raman Microscopy/ Spectroscopy in Agricultural Sciences and Food Technology, Pp. 3-14. London: Ubiquity Press. DOI: https://doi.org/10.5334/bbj.a. License: CC-BY 4.0 
physiological and molecular changes in plants (Ashraf et al. 2013). At the molecular level, drought stress induces expression of water-deficit-related genes. The products of those genes allow plants to protect cellular function and to adjust plant metabolism.

Tomato (Lycopersicon esculentum Mill.) is one of the most widely grown vegetables in the world. Tomato fruits are of special importance both as a fresh vegetable and as a component of food processing industry. However, most of the commercial tomato cultivars are drought sensitive at all stages of the development, with the seed germination and seedling growth being the most sensitive stages (Foulard et al. 2004). Similarly to many other vegetables, tomato has high water requirements (CA. $400-600 \mathrm{~mm}$ ha-1) and water supply is essential for successful production (Hanson \& May 2004).

Real-time PCR is a technique that measures quantity of target sequence in real time and that is commonly used toquantify DNA or RNA in a sample. Using sequence-specificprimers, the number of copies of a particular DNA or RNA sequence can be determined. By measuring the amountof amplified product at each stage during the PCR cycle, quantification is possible.SYBR Greenbased detection is the least expensive and easiest method available for real-time PCR. SYBR Green specifically binds double-stranded DNA by intercalating between base pairs, and fluoresces only when bound to DNA. Detection of the fluorescent signal occurs during the PCR cycle at the end of either the annealing or the extension stepwhen the greatest amount of double-stranded DNA product is present.

Expression of drought- related genes can reveil the role of their products in drought resistance mechanisms. Those informations can be helpful in the breeding efforts to produce tomato cultivars with the increased/sustained fruit quantity and quality in drought conditions.

\section{Materials, Methods and Notes}

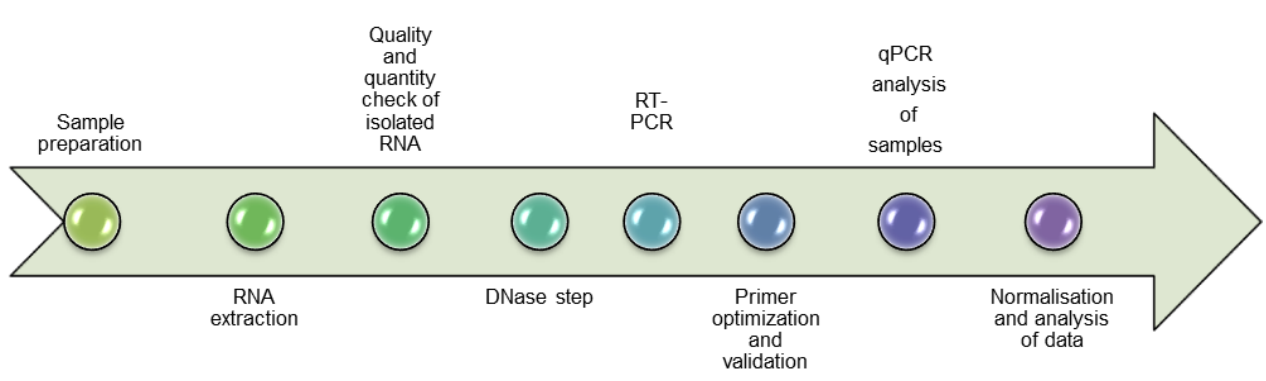

Figure 1: Phases of two-step RT-qPCR. 


\subsection{Sample preparation - tomato leaves}

Note:

- Only young and fully developed leaves should be collected. Old and damaged leaves are not a good material for qPCR analysis of drought-related genes.

- To avoid RNA degradation by RNase, collected samples should not melt at any moment after freezing in liquid nitrogen.

- To avoid cross-contamination, it is necessary to use clean tools for collecting of each leaf and to clean the grinder well after every sample with some DNA/RNA cleaning reagent.

2.1.1 Collect tomato leaves and put them into sterile, unused bags made from liquid-nitrogen proof material. Bags should be placed immediately into liquid nitrogen.

2.1.2. Grind collected leaves in grinder with liquid nitrogen.

2.1.3. Transfer around $150 \mathrm{mg}$ of leaf powder into clean $2 \mathrm{ml}$ tube.

2.1.4. Store tubes at $-80^{\circ} \mathrm{C}$ until analysis.

\subsection{RNA extraction}

Note:

- Method which includes using of TRIzol REAGENT is one of the most effective methods of RNA isolation. The procedure with TRIzol REAGENT can be completed within 1 hour and the recovery of undegraded mRNAs is 30-150\% greater than/ when compared to other methods of RNA isolation. For the extraction from tomato leaves, this method is efficient and RNA has good quality. In this study, TRIzol REAGENT-Thermo Fisher Scientific was used.

The extraction of RNA from tomato leaves is done by following steps:

a) HOMOGENIZATION

2.2.1. Homogenize tissue samples in TRI Reagent $\left(1 \mathrm{ml} / 100 \mathrm{mg}\right.$ tissue $\left.{ }^{\star}\right)$. Mix well with vortex.

2.2.2. Store the homogenate for 5 minutes at room temperature. *The sample volume should not exceed $10 \%$ of the volume of TRIzol because an insufficient volume can result in DNA contamination of isolated RNA.

b) SEPARATION

2.2.3. Add $200 \mu \mathrm{l}$ of chloroform per $1 \mathrm{ml}$ of TRI Reagent, cover the samples tightly and shake vigorously for 15 seconds with vortex. 
2.2.4. Store the resulting mixture at room temperature for 2-15 minutes.

2.2.5. Centrifuge at maximum speed for 15 minutes at $4 \mathrm{C}$.

2.2.6. Transfer the $500 \mu \mathrm{l}$ of the aqueous phase to a new tube.

c) RNA PRECIPITATION

2.2.7. Add $500 \mu \mathrm{l}$ of isopropanol and mix quickly by inversion.

2.2.8. Store samples at room temperature for 5-10 minutes and centrifuge at max.speed for 10 minutes at $4^{\circ} \mathrm{C}$.

d) RNA WASH

2.2.9. Remove the supernatant and wash the RNA pellet (by vortexing) with $1 \mathrm{ml} 75 \%$ ethanol.

2.2.10. Subsequent centrifugation at $10000 \mathrm{rpm}$ for 5 minutes at $4^{\circ} \mathrm{C}$.

e) RNA SOLUBILIZATION

2.2.11. Remove the ethanol wash and briefly air-dry the RNA pellet for 5-10 min. It is important not to completely dry the RNA pellet because drying will decrease its solubility.

2.2.12. Dissolve RNA in water RNase-free $(50 \mu \mathrm{l})$ by passing the solution a few times through a pipette tip, vortex if necessary.

2.2.13. Store at $-20^{\circ} \mathrm{C}$ for short periods, otherwise store at $-80^{\circ} \mathrm{C}$.

\subsection{Quality and quantity check of isolated RNA}

Validation of quality and amount of isolated RNA is required. Quality check can be done by agarose gel electrophoresis. In this study, RNA quality control was done on $1 \%$ agarose gel. Into precast gelsmixture of $2 \mu \mathrm{l}$ RNA, $3 \mu \mathrm{l}$ of RNasefree $\mathrm{H}_{2} \mathrm{O}$ and $1 \mu \mathrm{l}$ of loading buffer was loaded. General information about RNA integrity can be obtained by observing the staining intensity of the major ribosomal RNA (rRNA) bands and any degradation products ${ }^{*}$. In this work, total RNA formed clear $28 \mathrm{~S}$ and $18 \mathrm{~S}$ rRNA bands (ratio 2:1), which is a good indication that the RNA had good quality.

Quantification of RNAs was done by NanoDrop spectrophotometer and samples were diluted, until concentration of $200 \mathrm{ng}$ of RNA/ $1 \mu \mathrm{l}$ of sample was obtained. For extracted RNA, the ration of 260/280 close to 2 indicates the high-quality material, suitable for further analyses.

* Partially degraded RNA will have a smeared appearance, will lack the sharp rRNA bands, or will not exhibit the 2:1 ratio of high quality RNA. Completely ensure the gel was run properly. Degraded RNA will appear as a very low molecular weight smear. Use of RNA size markers on the gel will allow the size of any bands or smears to be determined and will also serve as a good control to 


\subsection{DNase step}

Note:

- Important controle in RT-qPCRanalysis is DNase step, in which the isolated RNA is treated with DNase enzyme. This step ensures that analyzed samples of RNA are clean from genomic DNA contamination that can affect results: The false-positive RT-PCR product could come from the presence of genomic DNA instead of RNA. DNase used in this work was part of the RNase-Free DNase Qiagen kit (ref: 79254).

Before performing DNase step, it is required to do efficacy test of DNase buffer and DNase enzyme. Buffer test and DNase efficacy test are performed with 2-3 fold concentrated samples of RNA, compared to concetration used for RTqPCR reaction.

Three test tubes should be made:

Tube $0=18 \mu \mathrm{L}$ H20 RNase free $+2 \mu \mathrm{L}$ RNA

Tube $1=16 \mu \mathrm{L}$ H20 RNase free $+2 \mu \mathrm{L}$ RNA $+2 \mu \mathrm{L}$ DNase buffer

Tube $2=15.8 \mu \mathrm{L}$ H20 RNase free $+2 \mu \mathrm{L}$ RNA + $2 \mu \mathrm{L}$ DNase buffer + 0.2 $\mu \mathrm{LDN}$ ase

\subsubsection{DNase buffer test}

2.4.1.1. Incubate tubes 0,1 and 2 during $30 \mathrm{~min}$ at $37^{\circ} \mathrm{C}+5 \mathrm{~min}$ at $65^{\circ} \mathrm{C}$. The purpose of incubation $\left(\right.$ at $65^{\circ} \mathrm{C}$ ) is inactivation of DNase, present only in tube 2.

2.4.1.2. Mixture from tubes 0 and 1 should be run on agarose gel, in order to check that DNase buffer did not degrade RNAs.

2.4.1.3. Tubes should be kept at $-80^{\circ} \mathrm{C}$ for DNase test.

\begin{tabular}{|c|c|c|}
\hline Preparation of Tris- $\mathrm{HCl}(1 \mathrm{M} \mathrm{pH} 8,00)$ & 7 & DNase solution \\
\hline $605,7 \mathrm{mg}$ of Tris & & $2 \mathrm{ml}$ of $1 \mathrm{M}$ Tris- $\mathrm{HCl} \mathrm{pH}=8,00$ \\
\hline $235 \mu \mathrm{L}$ of $37 \% \mathrm{HCL}$ & & $0,4 \mathrm{ml} \mathrm{MgCl}$ \\
\hline Adjustement of $\mathrm{pH}=8,00$ & & $0,4 \mathrm{ml}$ DTT $(0,1 \mathrm{M})$ - from DNase kit) \\
\hline $5 \mathrm{~mL}$ of $\mathrm{H}_{2} \mathrm{O}$ & & $5 \mathrm{~mL}$ of $\mathrm{H}_{2} \mathrm{O}$ \\
\hline Preparation of $\mathrm{MgCl}_{2} 0,5 \mathrm{M}$ & & $\downarrow$ \\
\hline $508 \mathrm{mg}$ of $\mathrm{MgCl}_{2}$ & & Filter DNase buffer by $0.22 \mu \mathrm{M}$ filter \\
\hline $5 \mathrm{~mL}$ of $\mathrm{H}_{2} \mathrm{O}$ & - & Store at $-20^{\circ} \mathrm{C}$ \\
\hline
\end{tabular}

Table 1: DNase buffer $(5 \mathrm{ml})$ preparation protocol. 


\subsubsection{DNase test}

Note:

- This test is in fact a real time PCR with a housekeeping gene and SYBR Green as fluorescent probe. The aim is to check if there is still genomic DNA in the purified RNA sample after the DNase step treatment.

- DNase test is done in presence of positive (tomato RNA) and negative $\left(\mathrm{H}_{2} \mathrm{O}\right)$ control.

- For DNase test, it is recommended to use the products from DNase buffer test (from 2.4.1.) - content from tube 1 (sample without DNase enzyme) and tube 2 (sample with DNase enzyme).

\begin{tabular}{|l|l|l|}
\hline $95^{\circ} \mathrm{C}$ & $10 \mathrm{~min}$ & 1 cycle \\
\hline $95^{\circ} \mathrm{C}$ & $30 \mathrm{sec}$ & \multicolumn{1}{|}{} \\
\cline { 1 - 2 } $55^{\circ} \mathrm{C}$ & $1 \mathrm{~min}$ & \multirow{2}{*}{40 cycles } \\
\cline { 2 - 2 } $72^{\circ} \mathrm{C}$ & $30 \mathrm{sec}$ & \\
\hline
\end{tabular}

Table 2: Real-time PCR conditions for DNase test.

Results should be checked. There should be no DNA in samples and no PCR products in qPCR reaction.

\subsubsection{DNasestep}

Note:

- Before DNase step on all samples, it is important to dilute RNA until $2 \mu \mathrm{g} /$ $\mu \mathrm{l}$ concentrations is obtained. The easiest way is to dilute samples in wells of the plate, so the next step is easier. In this study after dilution each well contained $17.8 \mu \mathrm{L}$ of diluted RNA.

2.4.3.1. In each well add $2 \mu \mathrm{L}$ of DNase buffer and $0.2 \mu \mathrm{L}$ of DNase

2.4.3.2. Incubate 30 minutes at $37^{\circ} \mathrm{C}$.

2.4.3.3. Incubate plate for 5 minutes at $65^{\circ} \mathrm{C}$ in order to inactivate DNase.

2.4.3.4. Store plate at $-80^{\circ} \mathrm{C}$.

\subsection{Two-step RT-qPCR}

There are two approaches to RT-qPCR. First one is one-step RT-qPCR that combines the RT reaction and PCR in one plate. Second one is two-step RT$\mathrm{qPCR}$ where the RT reaction is performed separately from the qPCR. In this 


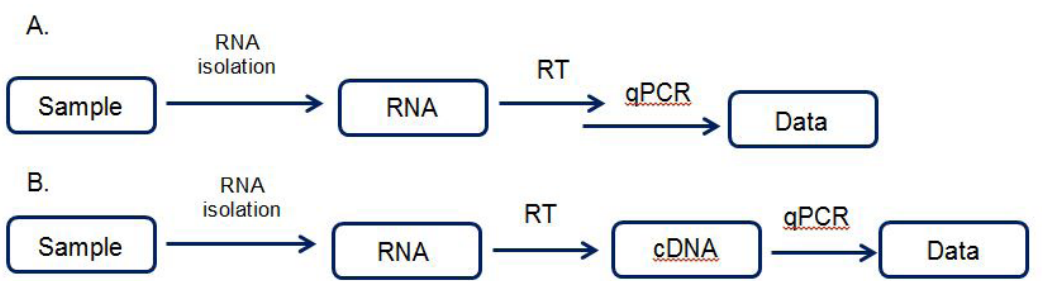

Figure 2: A. One step RT-qPCR B. Two-step RT-qPCR.

study, we used two-step approach because it provides bigger control of processes and higher level of flexibility. This approach also simplifies any required troubleshooting.

\subsubsection{RT TEST}

Note:

- The aim of this test is to check the efficacy of the buffer and of the DNase during RT-PCR before to make this step on all the samples. For this test, 2-3 samples can be used or a pool of RNA samples. If we have different conditions, it's better to have one pool by condition (in this case, control and drought stress).

\begin{tabular}{|c|c|c|c|c|c|}
\hline & & $\begin{array}{c}\text { Without } \\
\text { superscript }\end{array}$ & $\begin{array}{c}\text { Without } \\
\text { superscript }\end{array}$ & $\begin{array}{c}\text { With } \\
\text { superscript }\end{array}$ & $\begin{array}{c}\text { With } \\
\text { superscript }\end{array}$ \\
\hline & $\begin{array}{c}\mathrm{H}_{2} \mathrm{O} \\
\text { test }\end{array}$ & Condition 1 & Condition 2 & Condition 1 & Condition 2 \\
\hline Oligo $(\mathrm{dT}) 21$ & $1 \mu \mathrm{l}$ & $1 \mu \mathrm{l}$ & & $1 \mu \mathrm{l}$ & \\
\hline RNA & / & $10 \mu \mathrm{l}$ & & $10 \mu \mathrm{l}$ & \\
\hline dNTP Mix & $2,5 \mu \mathrm{l}$ & $2,5 \mu \mathrm{l}$ & & $2,5 \mu \mathrm{l}$ & \\
\hline $\mathrm{H}_{2} \mathrm{O}$ & $10 \mu \mathrm{l}$ & l & & l & \\
\hline Incubation & \multicolumn{5}{|c|}{5 min at $65^{\circ} \mathrm{C}+5 \min$ on ice } \\
\hline Buffer (kit) & $4 \mu \mathrm{l}$ & $4 \mu \mathrm{l}$ & & $4 \mu \mathrm{l}$ & \\
\hline DTT (kit) & $1 \mu \mathrm{l}$ & $1 \mu \mathrm{l}$ & & $1 \mu \mathrm{l}$ & \\
\hline Superscript III & $0,75 \mu \mathrm{l}$ & / & & $0,75 \mu \mathrm{l}$ & \\
\hline Incubation & \multicolumn{5}{|c|}{$60 \mathrm{~min}$ at $42^{\circ} \mathrm{C}+5 \mathrm{~min}$ at $70^{\circ} \mathrm{C}$} \\
\hline
\end{tabular}

Table 3: RT test. 
This test is done by RT PCR. After last incubation, results should be checked on agarose gel. On gel should be checked negative controls $\left(\mathrm{H}_{2} \mathrm{O}\right.$ and RT without superscript), and RT product with superscript. Negative controls do not contain DNA, so there should not be present DNA traceson gel. DNA ladders are used in gel electrophoresis to determine the size and quantity of testing DNA fragment. DNA leader can be also used as positive control, to confirm the formation of good smear - one clear band of DNA. If two bands appear, it could indicate that some of the products are single stranded. Presence of big smear indices that DNA is degraded.

\subsubsection{RT}

If initial RT test (2.5.1.) is successful, the RT procedure should be done for all samples. During this procedure the cDNA of each sample is synthesized. Once cDNA is made, $2 \mu \mathrm{l}$ of every sample should be mixed into a pool (or multiple pools for multiple conditions) that is going to be used for primer validation.

The rest of cDNA should be stored in plate at $-80^{\circ} \mathrm{C}$.

\begin{tabular}{|l|l|l|l|l|}
\hline & 1 sample & 50 samples & 98 samples & \\
\hline RNA & $10 \mu \mathrm{L}$ & $10 \mu \mathrm{L}$ & $10 \mu \mathrm{L}$ & by well \\
\hline oligo(dT) 21 & $1 \mu \mathrm{L}$ & $50 \mu \mathrm{L}$ & $98 \mu \mathrm{L}$ & $3,5 \mu \mathrm{L}$ by well \\
\hline dNTP Mix & $2,5 \mu \mathrm{L}$ & $125 \mu \mathrm{L}$ & $245 \mu \mathrm{L}$ & \\
\hline Incubation & $5 \mathrm{~min}$ at $65^{\circ} \mathrm{C}+5 \mathrm{~min}$ on ice & \\
\hline Buffer (kit) & $4 \mu \mathrm{L}$ & $200 \mu \mathrm{L}$ & $392 \mu \mathrm{L}$ & $5,75 \mu \mathrm{L}$ by well \\
\hline DTT (kit) & $1 \mu \mathrm{L}$ & $50 \mu \mathrm{L}$ & $98 \mu \mathrm{L}$ & \\
\hline Superscript III & $0,75 \mu \mathrm{L}$ & $37,5 \mu \mathrm{L}$ & $73,5 \mu \mathrm{L}$ & \\
\hline Incubation & $60 \mathrm{~min}$ at $42^{\circ} \mathrm{C}+5 \mathrm{~min}$ at $70^{\circ} \mathrm{C}$ & \\
\hline
\end{tabular}

Table 4: RT PCR.

\subsection{Primer optimization and validation}

Primer optimization and validation are essential, even when using primers that have been predesigned and commercially obtained. Optimization is required to ensure that the primer is as sensitive as it is required and that it is specific to the gene of interest.

Primer validation should be carried out on a pool of all available cDNAs (pool of cDNA made from all analyzed samples). In this study, one pool of cDNAs was made from samples exposed to drought stress and second pool is made from control samples. Both pools are diluted with ultra-pure water $(10 \mu \mathrm{l}$ of cDNA pool and $90 \mathrm{Ml}$ of ultra-pure water). Dilutions are kept at $-20^{\circ} \mathrm{C}$. Primers also should be diluted to obtain different concentrations $\left(10^{-3}-10^{-12}\right)$. Important data gotten from this step is also primer efficiency. 


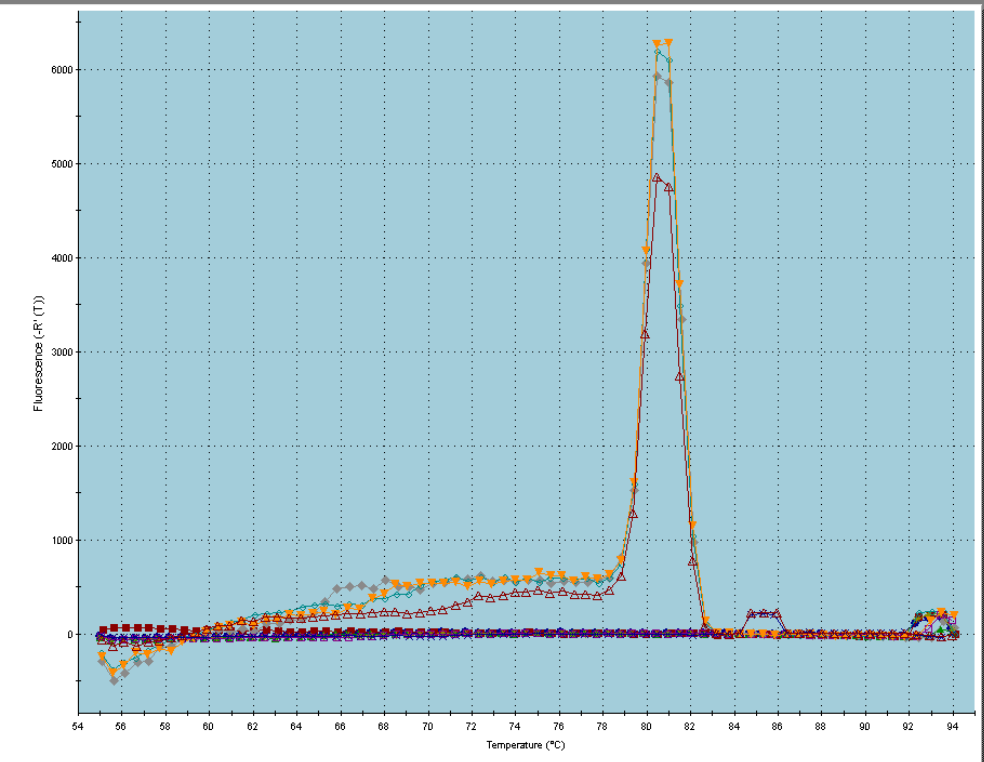

Figure 3: Dissociation peaks of primer with high specificity.

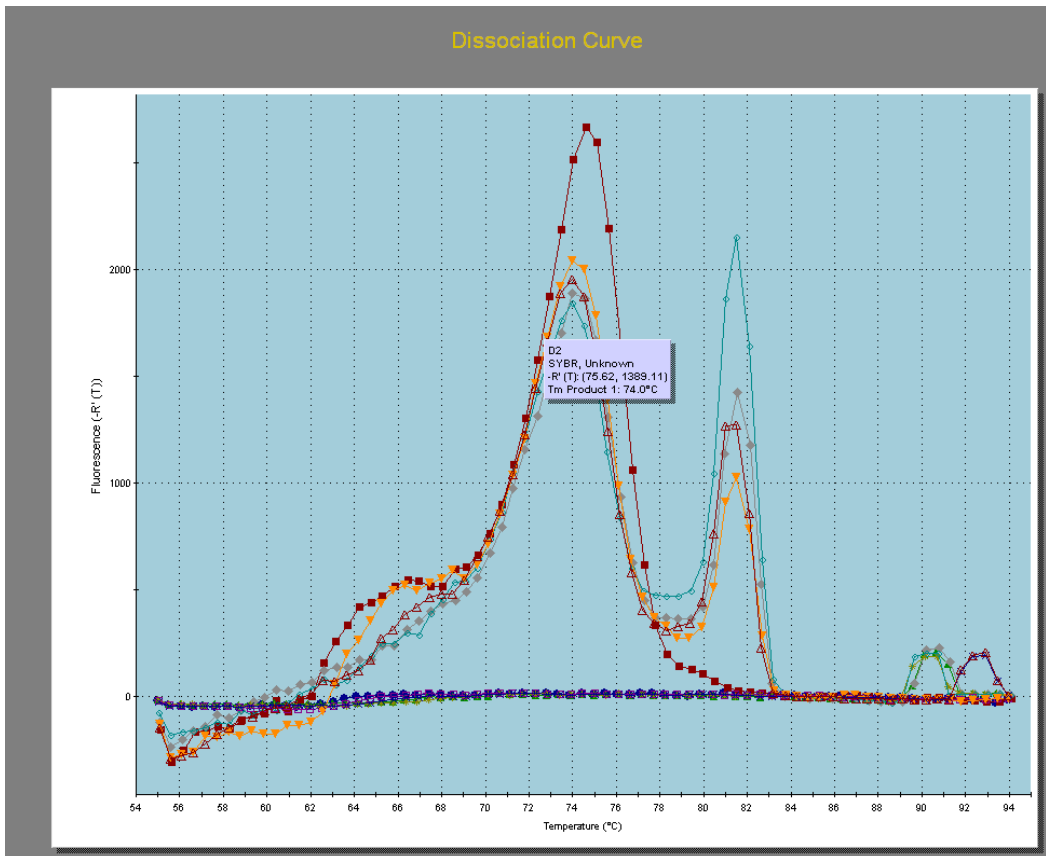

Figure 4: Dissociation peaks of primer with low specificity. 
Primer optimization is performed by qPCR which is done with a pool of samples for different primer dilution. This optimization is done to check the F-forwared and R-reverse primer are reacting properly at suggested reaction temperature and to find the most optimal dilution of primer that can be used a proper control when qPCR is done. In case of this study, primer dilutions from $10^{-7}$ to $10^{-8}$ showed the most optimal Ctvalues, so those dilutions are saved for positive controls for $\mathrm{qPCR}$ reactions.

In this study 12 (forward and reverse) primers were tested, but only 7 passed primer validation and optimization criteria. Except those seven genes, two housekeeping genes should also be analyzed as internal controls. For tomato, $\beta$-actin and Elongation factor One are good choice for tomato housekeeping genes.

\begin{tabular}{|l|l|l|}
\hline \multicolumn{1}{|c|}{ Primers } & \multicolumn{1}{|c|}{ F- forward } & \multicolumn{1}{c|}{ R-reverse } \\
\hline ZEP1-1 & ATCAACTGTGGGAACACCTG & ACGACCAGACATCTGCAATC \\
\hline ZEP1-2 & TGCATGGCCATAGAGGATAG & TGGATGACTCCAACTCGAAG \\
\hline PPC2 & TCAAACTCCACAGTGCGATG & CCGCAATTGGAAACGATG \\
\hline SlAPXcyto & CCTTTGTGATCCTGCTTTCC & CAGCTCTTCCAATCAGCATC \\
\hline NCED1 & AGGCAACAGTGAAACTTCCATCAAG & TCCATTAAAGAGGATATTACCGGGGAC \\
\hline SlAPXcp & TTGATCCACCTGAGGGTTTC & TCCCAAGCCTTCGTATTCTG \\
\hline abil & GGCAGCAAGGACAACATAAC & TGAGGCCAATTGTGTTGAAG \\
\hline
\end{tabular}

Table 5: Primers for quantitative real-time PCR (optimized and validated).

\section{7 qPCR analysis of samples}

Note:

- Each tested gene should be tested in two technical replicates.

- Except our genes of interest, two housekeeping genes should also be included in analysis.

- The proper negative and positive controls are essential for eliminating false-negative or positive results. In this regard, the following negative controls should be included in the real-time PCR test:

Negative control is in the well containing PCR reaction mix and nuclease-free water instead of the sample.

Positive controls are in the two wells containing PCR reaction mix and proper dilutions of corresponding primers $\left(10^{-7}\right.$ and $\left.10^{-8}\right)$ that are obtained in primer validation process and saved until qPCR analysis. Those positive controls are needed to validate accuracy of PCR reaction: it is important that values from our primer validation process are similar to those obtained in qPCR reaction with our samples. 
- During sample preparation and qPCR analysis, it is important to avoid contamination. If contamination occurs, it is essential to determine the source of contamination. More information about contamination detecting and solving the problem can be found at this link http://www.genequantification.com/mifflin-optimisation-report.pdf.

2.7.1. Dilute all samples $1 / 15$ ( $5 \mu \mathrm{l}$ of cDNA and $70 \mu \mathrm{l}$ of ultra-pure water) in the plate, in order in which all samples will be distributed during all analysis

2.7.2. Distribute $2 \mu \mathrm{l}$ of diluted cDNA into multiple plates. Those plates are "ready to use" and they can be stored at $-20^{\circ} \mathrm{C}$ for short periods.

2.7.3. Distribute $18 \mu \mathrm{l}$ of Master Mix into "ready to use" plate

2.7.4. Run qPCR and save the results.

To avoid potential contamination, it is desirable to separate samples from controls on qPCR plate (controls should be on the other part of the plate).

\begin{tabular}{|l|c|c|}
\hline Number of wells & 1 & 6 \\
\hline H20 & 6.2 & 37.2 \\
\hline $\begin{array}{l}\text { Briliant II Sybr Green Master Mix - } \\
\text { Agilent Technologies Stratagene }\end{array}$ & 10 & 60 \\
\hline Rox 1/500 & 0.3 & 1.8 \\
\hline primer & 1.5 & 9 \\
\hline
\end{tabular}

Table 6: Reagents mixture for real-time PCR.

\begin{tabular}{|l|l|l|}
\hline $95^{\circ} \mathrm{C}$ & $10 \mathrm{~min}$ & 1 cycle \\
\cline { 1 - 2 } $95^{\circ} \mathrm{C}$ & $30 \mathrm{sec}$ & \\
\cline { 1 - 2 } $55^{\circ} \mathrm{C}$ & $40 \mathrm{sec}$ & \multirow{2}{*}{40 cycles } \\
\cline { 2 - 2 } $72^{\circ} \mathrm{C}$ & $30 \mathrm{sec}$ & \\
\hline \multicolumn{3}{|c|}{ Dissociation curve } \\
\hline
\end{tabular}

Table 7:Real-time PCR conditions.

After qPCR, amplification plot and dissociation peak should be checked. For each gene, only one dissociation peak should be visible. It means that primer has good specificity. Ct values should be between 15 and 25, which mean that good level of expression is present. After qPCR analysis, it is necessary to do data normalization before statistical analysis.

Data normalization in real-time RT-PCR is one of the major steps in qPCR analysis. Data normalization can be carried out against an endogenous 
unregulated reference gene transcript or against total cellular DNA or RNA content. In this study, normalization is done by using two internal controls, which are basically two reference housekeeping genes. Transcripts of such genes, which are expressed at relatively high levels in all cells, make ideal positive controls for determining whether or not genes of interest are expressed in given types of samples under given conditions.

It is recommended to use between two and five validated stably expressed reference genes for normalization. It is important to use genes which are validated and which for sure have stable expression. Stability of reference genes can be determined by calculating their $M$ value $(M)$ or their coefficient of variation on the normalized relative quantities (CV). These values can then be compared against empirically determined thresholds for acceptable stability.

\section{Acknowledgements}

This work was funded by by EU Commission project AREA, no. 316004. I would like to thank to researchers from INRA (Avognon, France), especially Nadia Bertin and MatildeCausse for arranging our visit and Justine Gricourt for laboratory support.

\section{References}

Ashraf, M. \& Harris, P.J.C. (2013). Photosynthesis under stressful environments; An overview. Photosyntetica 51, 163-190, DOI: https://doi.org/10.1007/ s11099-013-0021-6

Foolad, M.R., Zhang, L.P. \& Subbiah, P. (2003). Genetics of drought tolerance during seed germination in tomato: inheritance and QTL mapping. Genome 46, 536-545. DOI: https://doi.org/10.1139/g03-035

Hanson, B. \& May, M. (2004). Effect of subsurface drip irrigation on processing tomato yield, water table depth, soil salinity, and profitability. Agricultural Water Management. 68, 1-17. DOI: https://doi.org/10.1016/j. agwat.2004.03.003

Molecular BioProducts (1997). Control of Contamination Associated with PCR and Other Amplification Reactions by Theodore E. Mifflin, Ph.D., DABCC, Retrieved from http://www.gene-quantification.com/mifflin-optimisationreport.pdf 